be four times as accurate as a corresponding groupfeeding trial. The question of the protein require. ments of pigs received early consideration. It was demonstrated that equally good results could be obtained, from the point of view of growth, economy of food conversion and carcass quality, when all-meal rations supplying only 7 per cent of white-fish meal were fed, as with diets much richer in protein. Moreover, it was shown that if the protein-rich concentrate was omitted altogether from the diet after $90 \mathrm{lb}$. live-weight, it was without the slightest effect on the rate of live-weight gain or on the leanness of the carcass. Considerable economies were therefore possible in the use of white-fish meal, which proved of great importance when supplies were short. The replacement of animal protein by vegetable protein plus minerals was also investigated.

On the death of Prof. T. B. Wood in 1930, Woodman became responsible for the sixth edition of "Rations for Livestock", the best-seller among the Bulletins of the Ministry of Agriculture. It became imperative in 1948 that the Bulletin should be almost entirely rewritten, and from this date Woodman assumed full responsibility as author. Woodman was also the author of the other bulletins- "Home Grown Feeding Stuffs" and "The Use of Oil Cakes and Extracted Meals" - which have lately been out of print. Finally, mention should be made of his contributions to Agriculture, during the War, of "Notes on Feeding Stuffs", which gave the results of research work at Cambridge and elsewhere, and were greatly appreciated by farmers and others.

No account of the work of Woodman would be complete without reference to his ability as a teacher. His great joy in life was in lecturing to the degree class at Cambridge. He was a born teacher and took infinite pains in the presentation of the material and had the gift of making a difficult subject seem easy.

He leaves a widow, a son and daughter, and a grandson.

R. E. Evans

\section{Dr. H. Wormald}

Harry Wormald, who died at his Maidstone home on December 10 last at the age of seventy-six, was distinguished for his pioneer work, over the past forty-five years, on the pathology of fruits and hops, and more particularly for his original researches on the two important groups of diseases, brown rot (Sclerotinia spp.) and bacterial canker (Pseudomonas mors-prunorum and Ps. prunicola Worm.), in both of which fields he became an authority of international repute.

Born a Yorkshireman, he first trained as a schoolteacher and for eight years taught a general curriculum in schools in Bradford and Leeds. It was therefore not until he was thirty years of age, in 1908, that with a Board of Education scholarship he went to London to read botany at the Royal College of Science (Imperial College of Science and Technology) under Prof. J. B. Farmer. Three years later he gained his A.R.C.S. and also the B.Sc. degree of the University of London with honours; and after a further year of research at the Royal College of Science, when he was awarded the diploms of the College, he went in 1911 to Wye College in Kent (University of London) as assistant in the Botany (Mycology) Department under E. S. Salmon. The dominating interest in fungal and bacterial diseases of fruits and hops which Wormald developed at Wye is reflected in the award of the D.Sc. degree in 1919 for his early publications on brown rot, and in his transfer in 1923 to the then young East Malling Research Station as the first head of its Plant Pathology Section. There he worked for twenty-two years under the inspiring directorship of $R$. $G$. Hatton, and as the beloved chief and mentor of a long succession of postgraduate students and colleagues. It was at East Malling that Wormald consolidated his early work on the brown rot and crown gall diseases, and initiated the brilliantly original etiological studies on the bacterial canker diseases of the stone fruits.

In 1936 Wormald was appointed assistant director at East Malling, and for ten years, from 1935, he edited the Station's Annual Report. In 1940 he became president of the British Mycological Society and was joint editor of the Transactions of that Society during 1931-45. He also served as a member of the Council of the Association of Applied Biologists (1937-39) and as a vice-president (1938-39).

In 1945, in his sixty-sixth year, Wormald finally retired from East Malling, and in the same year joined the staff of the Commonwealth Bureau of Horticulture and Plantation Crops, stationed at East Malling, where for seven years he exercised his linguistic gifts (he could translate fluently from seven languages, including Russian) as an abstractor of world horticultural literature.

In 1952, at the age of seventy-three, Wormald was obliged to retire from the Bureau because of the illness to which three years later he was to succumb, only, however, to continue at home, with the quiet and patient tenacity of purpose which characterized his whole research career, the preparation of new editions of his two principal works, the monograph "The Brown Rot Diseases of Fruit Trees" (Ministry of Agriculture and Fisheries), and the standard textbook on his subject, embracing the impressive corpus of his original research papers, "The Diseases of Fruits and Hops" (Crosby Lockwood and Son, Ltd.). With the devoted and unflagging support of his wife, these immense tasks were brought to a successful conclusion, and within six months of the publication of the new edition of his text-book he died.

$$
\text { R. V. HARRIS }
$$

\section{Mr. F. W. K. Gervers}

Frank Walter Kitchener Gervers was born on April 17, 1920. He went to school at Bradfield, where he became an enthusiastic member of the School Natural History Society and published a paper of unusual quality for a schoolboy on the biology of a small stream. When he left school in 1939 he followed a family tradition and joined the Regular Army. $\mathrm{He}$ served in the Royal Artillery in North Africa, Italy and India ; but his active military career was terminated by ill-health in 1946 and he decided to resume his interest in biology.

Gervers went to the University of Glasgow and during vacations worked in the laboratories at Pitlochry, Aberdeen and Lowestoft, and went to sea on the research vessels. After graduating he worked for a year with Dr. H. D. Slack on the biology of Loch Lomond, studying particularly the white fish or powan found there. In 1953, he joined the freshwater fisheries staff of the Ministry of Agriculture and Fisheries and carried out a most useful study of the food of coarse fish. He also took a large part in the 